\title{
INTRINSIC CULTURAL FACTORS THAT HELPED VIETNAM OVERCOME THE COVID-19 PANDEMIC COMPARED WITH OTHER COUNTRIES.
}

\author{
Ngoc Cindy Pham', Yuanqing Li², Claudio Schapsis', Tofazzal Hossain³, Huan Henry Pham', \\ Dov Fischerl, Jun Yang ${ }^{5}$
}

\author{
1. CUNY - Brooklyn College, New York, USA \\ 2. Dominican University - Chicago, USA \\ 3. PrimeAsia University, Dhaka, Bangladesh \\ 4. Houston Community College, USA \\ 5. University of Houston Victoria, USA
}

Correspondence: dr.ngocphamcindy@gmail.com

\section{ABSTRACT}

The Coronavirus Disease 2019 (COVID-19) pandemic emerged in Wuhan, China, spread nationwide and then onto many other countries between December 2019 and early 2020. The implementation of strict quarantine measures in Vietnam has kept a large number of people in isolation and has eventually put the disease under control. Social and physical distancing turned to be an efficient way of slowing the spread of disease and stopping chains of transmission of COVID-19 as well as preventing new ones from appearing (World Health Organization, 2020). Analyzing the World Health Organization (WHO) data, we could see a clear difference in the reported numbers between Vietnam, a developing country, and the USA, one of the leading developed countries in the western hemisphere. We tried to address the question if there are factors that helped local governments to implement helpful rules. We argue that Eastern Asian cultural traits played a role in reducing the spread of COVID-19. We recommend to take this commentary paper, and further research those cultural factors that positively affected the slowdown of the spread of the COVID-19 pandemic in Vietnam.

\section{KEYWORDS}

COVID-19, Intrinsic Cultural, Factors, Confucius

\section{INTRODUCTION}

The Coronavirus Disease 2019 (COVID-19) pandemic emerged in Wuhan, China, spread nationwide and then onto many other countries between December 2019 and early 2020. The implementation of strict quarantine measures in Vietnam has kept a large number of people in isolation and has eventually put the disease under control. Social and physical distancing turned to be an efficient way of slowing the spread of disease and stopping chains of transmission of COVID-19 as well as preventing new ones from appearing. [1]

We provide a table comparing timelines of events in Vietnam and USA and then turn to a discussion of Holstedes Theory to help address the differing cultural aspects of the comparisons. 
TABLE 1: COMPARING THE TWO COUNTRIES COVID-19 PANDEMIC TIMELINE

\begin{tabular}{|c|c|c|}
\hline TIMELINE & VIETNAM & USA \\
\hline $\begin{array}{l}\text { Dec. 31, } 2019 \\
\text { First cases reported in } \\
\text { Wuhan, China. [1] }\end{array}$ & No cases reported & No cases reported \\
\hline Jan 2020 & $\begin{array}{l}\text { The first two cases reported. The } \\
\text { individuals arrived from China. }\end{array}$ & $\begin{array}{l}\text { The first case reported in } \\
\text { Washington State. [2] }\end{array}$ \\
\hline Jan. 29 & $\begin{array}{l}\text { The Vietnamese Government, through } \\
\text { the Ministry of Health, deploys forty } \\
\text { mobile emergency response teams.[3] }\end{array}$ & $\begin{array}{l}\text { The formation of the Coronavirus } \\
\text { Task Force is announced by } \\
\text { President Donald Trump.[4] }\end{array}$ \\
\hline Early February & $\begin{array}{l}\text { Less than a dozen cases are reported by } \\
\text { the Vietnamese Government [5] }\end{array}$ & $\begin{array}{l}\text { Nine cases are confirmed on Feb. } 2 \\
\text { [6] }\end{array}$ \\
\hline Feb. 11 & $\begin{array}{l}\text { The 10th case confirmed in Vinh Phuc } \\
\text { triggers the quarantine of } 10,600 \\
\text { residents of the Son Loi village for } 14 \\
\text { days, which was finally removed on Mar. } \\
\text { 3. [7-9] }\end{array}$ & $\begin{array}{l}\text { Additional cases are reported in } \\
\text { California, mainly from evacuees } \\
\text { from China [10] }\end{array}$ \\
\hline Feb. $25 / 26$ & $\begin{array}{l}\text { Vietnam is temporarily free of COVID-19 } \\
\text { cases, as the } 16 \text { th was released from the } \\
\text { hospital after being tested negative. } \\
\text { Nevertheless, quarantine measures are } \\
\text { still in place. [1 1] }\end{array}$ & $\begin{array}{l}\text { President Trump asserts that 'When } \\
\text { you have } 15 \text { people, and the } 15 \\
\text { within a couple of days is going to } \\
\text { be down close to zero, that's a } \\
\text { pretty good job we've done.' [12] }\end{array}$ \\
\hline Mar. 16 & $\begin{array}{l}\text { The identification of } \\
\text { 'patient } 61 \text { ' triggers the closing of a } \\
\text { mosque in Saigon and the quarantine of } \\
\text { the whole Ninh Thuạn province. }[13,14]\end{array}$ & $\begin{array}{l}\text { President Trump releases guidelines } \\
\text { to limit discretionary travel and } \\
\text { social gatherings of } 10 \text { people or } \\
\text { more, but quarantine } \\
\text { recommendations are avoided. [15] }\end{array}$ \\
\hline End of March & $\begin{array}{l}\text { With little over } 200 \text { cases reported } \\
\text { nationwide the Vietnamese } \\
\text { Government ordered countrywide } \\
\text { isolation from Apr. } 1 \text { to Apr. 15. [16] }\end{array}$ & $\begin{array}{l}185,991 \text { cases and 3,809 deaths are } \\
\text { reported. Different states implement } \\
\text { disparate rules - no single policy } \\
\text { exists for the country. }\end{array}$ \\
\hline April $17-23$ & $\begin{array}{l}\text { No new cases were confirmed. The } \\
\text { death toll remains the same. [17] }\end{array}$ & $\begin{array}{l}\text { The count of total cases rises to } \\
862,605 \text { and the number of deaths } \\
\text { to } 44,038\end{array}$ \\
\hline May 5 & $\begin{array}{l}271 \text { confirmed cases, } 232 \text { recoveries, } \\
\text { and no deaths are reported }\end{array}$ & US Deaths crossed the 71,000 mark. \\
\hline
\end{tabular}




\section{HIGH POWER DISTANCE}

The cultural dimensions proposed by Hofstede [18] may help understand the reasons behind Vietnamese people's compliance with their government orders.

Like other East Asian countries, Vietnam applies the Confucian social philosophy in daily life. Compliance attitude toward orders from those who are in higher positions is rooted in Vietnamese society for thousands of years. For example, the saying from monarch times 'Quan $x u$ than tu, than bat tu bat trung' (aka When the King wants you to die, if you don't die, you are not loyal) shows that expectation of obedience. Therefore, Vietnamese people are more likely to listen and observe the Government's requests for staying home and keeping social distancing. In the case of Vietnam, data suggests that strict policy on social distancing and population compliance helped prevent the spread of Coronavirus.

Additionally, Confucian philosophy emphasizes the virtue of respect for parents, elders, and ancestors. Vietnamese children are taught - 'Kinh lao dac tho' (aka the youth should show respect to the elderly). A similar respect-based relationship can be found between Vietnamese teachers and students. The proverbs 'Ton su trong dao' (Respect the teacher, respect the education) and 'Nhat tu vi su, ban tu vi su' (A person that teaches you anything, big or small, is your teacher) explain why Vietnamese students will abide by their teachers' instructions to follow the social distancing rules dictated by the Government.

\section{COLLECTIVISM (VS. INDIVIDUALISM)}

Collectivist cultures emphasize organizational belonging and the preponderance of the interest of the group over the individual one. The saying 'Mot nguoi vi moi nguoi' (One should put the benefits of the group above his) is a reflection of that characteristic. In Vietnam, people are integrated into strong and cohesive groups under a collectivist society. These groups reward the individuals' unquestioned loyalty with protection. [19] In collectivistic cultures, group decisions are regarded as superior over any individual opinions. Therefore, individual initiative is not highly advocated, and differences in opinion or behaviors are not usually been accepted or recognized. [18]

In contrast, individualistic cultures celebrate the values and beliefs to be responsible for oneself, individual achievement, and emotional independence from organizations or groups. [18, 20] In those highly individualistic cultures, individuals are expected to pursue their interests.

\section{UNCERTAINTY AVOIDANCE}

Risk-taking attitude is also an important aspect to consider when evaluating the phenomenon Covid-19 spreading in Vietnam compared with the US. The uncertainty avoidance dimension of culture captures the 'extent to which a society, organization, or group relies on social norms, rules, and procedures to alleviate the unpredictability of future events.'[21] People in high uncertainty avoidance cultures focus on stability and security, whereas in low uncertainty avoidance cultures tend to demonstrate more tolerance towards unstructured and ambiguous situations.[22] Members in uncertainty avoidance societies appreciate confirmation and prefer predictability in their lives. [23] [19] Vietnamese people's tendency to avoid uncertainty is likely to influence their behaviors during the COVID-19 pandemic. When the COVID-19 situation is unclear, Vietnamese individuals (with higher uncertainty avoidance) turn to be more cautious than the American one (with lower uncertainty avoidance). That fact ended up protecting them better during the pandemic evolution.

\section{OTHER CULTURAL ASPECTS}

Vietnamese practice Confucius's group orientation. They follow the saying 'Phep vua thua le lang' (aka the will of the King yields to the people's customs). In other words, people are expected to follow their close group's rules. Hence, it will be difficult to break the neighborhood's rules. During the COVID-19 quarantine, once the neighborhood commits to social distancing rules, members will follow each other's behavior. If any individuals violate the rules, they can expect different levels of enforcements, from gentle reminders, to warnings, to reports to the neighborhood Board.

'The Dien' (face-saving) plays a big part in Vietnamese culture. Individuals are expected to act according to the social norms and rules to avoid public embarrassment. In Vietnamese society, when an individual "loses face," it means he loses his reputation and respect from others. One of the punishments Vietnamese law enforcers used during the COVID-19 social distancing toward those who violated the law was to publish his or her name in media outlets such as TV, local newspapers, and radio. These persons may also 
be reported to their workplace or school to receive further penalties for their wrongdoings. Those who visited a different city had to report themselves to the Neighborhood Management Board and self-quarantine for 14 days. Failure to report to the Board members and selfquarantine may result in being ashamed by the neighborhood, or even receive fines and jail time. Vietnamese people try to avoid such public shaming at all costs. On the other hand, those who follow the rule are praised as heroes on national media.

Moreover, Vietnamese try to keep harmony with their neighbors. They believe these people are whom they can count on in a time of need. The proverbs 'Ban anh em xa mua lang gieng gan' (aka your siblings who are living far away cannot help you as much as the next-door neighbor) or 'Hang xom toi lua tat den co nhau' (aka You have your neighbor when it is dark) reflect the belief of Vietnamese reliance on their close community. Thus, following the neighborhood's rule is what Vietnamese people try to do.

Furthermore, the culture of Vietnamese since the end of the civil war in 1975 is that "Tai mat la quan chung nhan dan" (aka the government's ears and eyes are people). It means the Government encourages people to report what they think is suspicious or wrong to officers of the law. In other words, the Vietnamese Government promotes peer to peer observance.

Vietnamese assign great importance to their family. People consider the family unit takes precedence over themselves. It is assumed that the harmony of the whole society depends on each family. Obedience, moderation, and self-restraint are highly valued among family members. Therefore, when the Government announced a policy towards COVID-19, people obeyed and self-restrained as a family. Some elements of social distancing were already present in Vietnamese people's lives, which helps to stop the chains of transmission of COVID-19. For example, Japanese and Chinese consider wearing a mask in public as standard behavior, while most Americans believe it is unusual and awkward.

\section{CONCLUSION - SOME TRADEOFFS}

The success of the Vietnamese Government in stopping the spread of COVID-19 in their country shows that the strict rules on social distancing indeed helped prevent a high rate of cases and deaths. They imposed mandatory 14 days quarantine in national centres for those who arrived from other countries and restricted gatherings of people. Vietnamese individuals strictly followed these laws, mostly because of the cultural implications presented in this paper.

Obviously, the conclusion to the saga of COVID-19 has not yet been written. While Asian countries in general, including China, seemed to have fared better than the West in eliminating the virus so far, it is not clear what the social costs have been in these countries. Would Americans agree to lose their privacy freedoms for Chinalike surveillance if that meant a lower risk of death and infection? For some Americans, founding-father Patrick Henry's phrase 'give me liberty or give me death' would apply not only to a foreign power but against a virus. [24] There are deep cultural and historical reasons for American individualism that address both the value of the individual's physical life and the intellectual prerogative to live as the individual sees fit. In terms of value of individual life, the historical source is the Judeo-Christian sanctity for human life. While Asian Confucianism places a clear preference of public survival over individual survival, this is not so in Jewish and Christian teachings, which do not allow the sacrifice of an individual life to save the lives of many others. [25] Consider a situation where a forced quarantine would endanger the life of the individual but would protect the life of the community. Such a move to sacrifice the individual life for the greater community may be acceptable under Confucianism but not under Judaism and Christianity.

The second aspect of Western individualism is the intellectual prerogative to choose in defiance of authority. This aspect derives from ancient Greek philosophy which respected logic over traditional consensus. In fact, the hero of Greek philosophy, Socrates, was put to death because he refused to conform intellectually to that of the majority consensus. A prime example of such individualism today is Elon Musk, who openly defied the lockdown restrictions of his California plant. Musk [26] tweeted: 'Tesla is restarting production today against Alameda County rules. I will be on the line with everyone else. If anyone is arrested, I ask that it only be me.' The confidence to openly defy albeit-local government officials is a testament to the American respect for individual points of view.

In the long-run both Asian and Western societies will have to grapple with the questions: (1) At what point do individual liberties cost too much in terms of human lives 
and (2) At what point does increased safety and security from the disease cost too much in terms of restrictions on liberty and encroachment on privacy?

\section{References}

1. World Healt Organization. WHO | Novel Coronavirus China: World Health Organization; 2020 [updated 2020-01-13 15:42:15. Available from: https://www.who.int/csr/don/12-january-2020-novelcoronavirus-china/en/.

2. Patel, Susan IG, Lindsay K, Suxiang T, Xiaoyan L, Steve $L$, et al. First Case of 2019 Novel Coronavirus in the United States. https://doiorg/101056/NEJMoa2001191. 2020.

3. Khỏe S. 40 đội phản ứng nhanh ứng phó virus corona sẵn s? ng cho tình huống xấu nhất 2020 [updated 2020-01-29. Available from: https://nld.com.vn/news20200128224950267.htm.

4. Whitehouse T. Statement from the Press Secretary Regarding the President's Coronavirus Task Force | The White House: @whitehouse; 2020 [Available from: https://www.whitehouse.gov/briefingsstatements/statement-press-secretary-regardingpresidents-coronavirus-task-force/.

5. TẾ BY. Trang tin về dịch bệnh viêm đường hô hấp cấp covid-192020 [Available from: https://ncov.moh.gov.vn/ban-do-vn.

6. Reuters. Ninth case of fast-moving Coronavirus confirmed in U.S: @ReutersUK; 2020 [updated 2020-0203. Available from: https://uk.reuters.com/article/ukchina-health-usa-california-idUKKBN1ZX01P.

7. VnExpress. Vinhh Phúc cô lập vùng dịch - VnExpress: @VnEnews; 2020 [Available from: https://vnexpress.net/vinh-phuc-co-lap-vung-dich4054265.html.

8. VnExpress. Sơn Lôi hết cách ly - VnExpress: @VnEnews; 2020 [Available from: https://vnexpress.net/son-loi-hetcach-ly-4063752.html.

9. Xuyen B. Vietnam quarantines area with 10,000 residents over Coronavirus rfi.fr2020

10. Ap. 2nd evacuee from China tests positive for Coronavirus: @kcranews; 2020 [updated 2020-02-13. Available from: https://www.kcra.com/article/2ndcase-new-coronavirus-confirmed-among-chinaevacuees/30902073.
11. ZingNews. Bệnh nhân thứ 16 nhiễm virus corona xuất viện hôm nay 2020 [updated 2020-02-25. Available from: https://zingnews.vn/zingnews-post1051503.html.

12. Rieger JM. Analysis | The Trump administration has contradicted itself on Coronavirus no fewer than 20 times in less than six weeks 2020 [Available from: https://www.washingtonpost.com/politics/2020/03/09/ trump-administration-has-contradicted-itselfcoronavirus-no-fewer-than-14-times-less-than-month/.

13. Cong $\mathrm{H}$. Saigon mosque closed after followers' contact with Covid-19 patient - VnExpress International VnExpress: @VnEnews; 2020 [Available from: https://e.vnexpress.net/news/news/saigonmosque-closed-after-followers-contact-with-covid-19patient-4071 122.html.

14. Nhân T, Lâm L, Hà Q. Ninh Thuận phong tỏa khu dân cư Văn Lâm 3 Thanh Nien2020 [updated 2020-03-18. Available from: https://thanhnien.vn/content/OTM2NDQ0.html.

15. Bacon J, Ortiz JL. Coronavirus live updates: Restrictions could last months; Canada closes border; McDonald's closes dining rooms USA Today: @usatoday; 2020 [Available from: https://www.usatoday.com/story/news/health/2020/0 3/16/coronavirus-live-updates-us-death-toll-risescases-testing/5053816002/.

16. Nguyen $X Q$, Uyen NDT. Vietnam Orders 15-day Nationwide Isolation from April 1 Bloomberg: @bpolitics; 2020 [updated 2020-03-31T05:15:03.299Z. Available from: https://www.bloomberg.com/news/articles/2020-0331 /vietnam-orders-15-day-nationwide-isolation-fromapril-1.

17. VnExpress. Chiều nay không ghi nhận thêm ca nhiễm nCoV - VnExpress: @VnEnews; 2020 [Available from: https://vnexpress.net/chieu-nay-khong-ghi-nhanthem-ca-nhiem-ncov-4087050.html.

18. Hofstede G. Culture's consequences: International differences in work-related values: sage; 1984.

19. Hofstede G, Hofstede GJ. Organisationer och kulturer. 2005.

20. Cullen JB, Parboteeah KP. Multinational management: Cengage Learning; 2013.

21. House RJ, Hanges PJ, Javidan M, Dorfman PW, Gupta $\vee$. Culture, leadership, and organizations: The GLOBE study of 62 societies: Sage publications; 2004. 
22. Lee SM, Peterson SJ. Culture, entrepreneurial orientation, and global competitiveness. J World Bus. 2000;35(4):401-16.

23. Steensma, H. K., Marino, L., Weaver, K. M., \& Dickson, P. H. (2000). The influence of national culture on the formation of technology alliances by entrepreneurial firms. Academy of management journal, 43(5), 951973.

24. Reuters Fact Check (2020, April 29). False claim: The death rate of the new coronavirus is 0.004 percent.

Accessed May 11, 2020 at

https://www.reuters.com/article/uk-factcheck-coviddeath-rate-point-004/false-claim-the-death-rate-ofthe-new-coronavirus-is-0-004-percent-idUSKBN22B2GJ

25. Shurpin, Y. (n.d.). "The Trolley Problem" in Judaism: Sacrifice One Life to Save Many? Chabad.org accessed May 11, 2020 at https://www.chabad.org/library/article_cdo/aid/4372 124/jewish/The-Trolley-Problem-in-Judaism.htm

26. Musk, Elon (2020, May 11). "Tesla is restarting production today against Alameda County rules. I will be on the line with everyone else. If anyone is arrested, I ask that it only be me." Twitter accessed on May 11, 2020

https://twitter.com/elonmusk/status/125994559380522 1891 